\title{
Family functioning in adolescents with major depressive disorder: A comparative study
}

\author{
Dinâmica familiar de adolescentes com \\ transtorno depressivo maior: \\ um estudo comparativo
}

\author{
Marilia Luiz PEREIRA ${ }^{1}$ \\ Marcos Pacheco de Toledo FERRAZ ${ }^{1}$ \\ Doris Lieth Nunes PEÇANHA ${ }^{2}$ \\ Maria Eugenia MESQUITA ${ }^{1}$ \\ Maria Eliza Pupo FINAZZI ${ }^{3}$ \\ Isabel Altenfelder Santos BORDIN'
}

\begin{abstract}
The goal of this study was to evaluate family functioning in two groups of adolescents: adolescents with major depressive disorder (cases) and adolescents with no psychiatric disorders (controls). A total of 18 adolescents (13-18 years) and their first-degree relatives $(N=70)$ were evaluated. Cases and controls were matched for the adolescent's age, gender, level of education, number and age of siblings, parental marital status, and economic condition. A family therapist conducted the Structured Family Interview with each family to evaluate nine family functioning dimensions (communication, rules, roles, leadership, conflict, aggressiveness, affect, individuation, and integration). The interview transcripts were independently rated by two different family therapists blinded to case-control status, i.e., without knowing whether they were evaluating cases or controls. The raters scored all interview items using a standardized coding system (overall agreement $=83.5 \%$ ), and when compared to the controls, the cases showed lower mean scores in seven dimensions, particularly affect $(p=0.0078)$. There was no difference between cases and controls regarding the dimensions rules and leadership. Difficulty in expressing affect in parent-child relationship was the main disturbance in the families of depressive adolescents evaluated.
\end{abstract}

Keywords: Adolescent; Affect; Comparative study; Family relations; Depressive disorder, Major.

\section{$\nabla \nabla \nabla$}

1 Universidade Federal de São Paulo, Departamento de Psiquiatria, Setor de Psiquiatria Social. R. Borges Lagoa, 570, cj. 51, 04038-000, São Paulo, SP, Brasil. Correspondência para/Correspondence to: M.L. PEREIRA. E-mail: <marilialpereira@hotmail.com>.

2 Universidade Federal de São Carlos, Departamento de Psicologia, Laboratório de Vivência Intrapsíquica e Desenvolvimento Ambiente Organizacional. São Carlos, SP, Brasil.

3 Universidade de São Paulo, Instituto de Psiquiatria, Hospital das Clínicas. São Paulo, SP, Brasil.

Article based on the dissertation of M.L. PEREIRA, entitled "Dinâmica familiar de adolescentes com transtorno depressivo: um estudo comparativo". Universidade Federal de São Paulo, 2008. 


\section{Resumo}

Avaliar a dinâmica familiar em dois grupos de adolescentes, um com transtorno depressivo maior (casos) e outro sem transtornos psiquiátricos (controles), totalizando 18 adolescentes (13-18 anos) acompanhados de seus pais e irmãos $(N=70)$. Pareou-se casos e controles segundo idade, sexo, escolaridade, número e idade dos irmãos, estado civil parental e condição econômica. Uma terapeuta familiar aplicou a Entrevista Familiar Estruturada a cada família, avaliando nove dimensões da dinâmica familiar (comunicação, normas, papéis, liderança, conflito, agressividade, afeto, individualização, integração). As sessões transcritas foram independentemente avaliadas por duas outras terapeutas familiares que desconheciam se as famílias constituíam casos ou controles. A pontuação dos itens da entrevista baseou-se em um sistema de codificação padronizado (concordância geral $=83,5 \%$ ). Comparados aos controles, os casos obtiveram médias de escores mais baixas em sete dimensões, especialmente afeto $(p=0,0078)$; não houve diferença nas dimensões normas e liderança. A dificuldade em expressar afeto nas relações entre pais e filhos foi a principal disfunção nas familias dos adolescentes deprimidos avaliados.

Palavras-chave: Adolescente; Afeto; Estudo comparativo; Relações familiares; Transtorno depressivo maior.

Family functioning is closely related to the physical and psychological well-being of family members and its impairment affects the family as a whole. High levels of parent-child conflict and disagreement have a negative impact on adolescents' mental health (Birmaher et al., 2004; Sheeber, Hops, \& Davis, 2001). Moreover, psychopathology such as depression can appear whenever the basic needs for individual development are not provided for by the social and physical environment (Puissant, Gauthier, \& Oirbeek; 2011). The recognition that depressive disorders occur in an interpersonal context calls greater attention to the role of the family environment and its interaction processes as relevant factors to the development of depressive disorders during adolescence. Indeed, according to Sheeber et al. (2001; 2009), family relations are important predictors of depression in adolescents.

Weich, Patterson, Shaw, and Stewart-Brown (2009) conducted a systematic review of large longitudinal studies of 10 or more years' duration with prospective data on relationships in the home during childhood (parent-parent or parent-child) and measures of common psychiatric disorders in adulthood. This review included 23 papers reporting data from 16 cohorts. The authors found that abusive relationships predicted depression, while maternal emotional unavailability in early life predicted suicide attempts in adolescence. These studies highlight the need to minimize harm associated with dysfunctional parent-child relationships.
Literature on the association between family functioning and depressive disorders in children and adolescents focuses on two main groups: families with depressive children/adolescents or children/ adolescents with depressive parents. Regarding studies on families with depressive children/ adolescents, attention is given to parental psychopathology, negative life events, and family conflict (Hughes \& Gullone, 2008; Kaslow, Deering, \& Rascusin, 1994). Depressed children/adolescents describe their families as less cohesive and understanding, more controlling, more conflicting, less able to communicate effectively, and as having higher levels of expressed emotions than do their non-depressed peers (Birmaher et al., 2004; Kaslow et al., 1994; Stein et al., 2000). However, few studies on family interaction patterns associated with depression in children/adolescents include family interaction observations based on multiple sources (parents and children/adolescents).

Dysfunctional family communication may be associated with the development or maintenance of depression in adolescents (Slesnick \& Waldron, 1997). Moreover, adverse family environments characterized by the absence of warm and supportive interactions and by the presence of elevated levels of conflict and criticism are associated with depressive disorders during adolescence (Sheeber, Davis, Leve, Hops, \& Tildesley, 2007). Birmaher et al. (2004) evaluated the family relationship of depressed children and adolescents and compared it to that of normal controls and 
found it to be characterized not only by higher levels of conflict, hostility, rejection, and control, but also by lower levels of cohesion, support, and communication. These conflictual relationships led to recurrence of disorders and poor response to treatment, tending to persist even after the remission of the depressive disorders. When looking at family risk factors for youth depression, researchers and clinicians must consider parental rearing style, parent-child attachment, support, marital conflict, and conflict between parents and their offspring (Restifo \& Bogels, 2009).

Family system theory defines family as an organized whole in which all elements are interdependent and each family member influences and is influenced by the other members. An individual's behavior is viewed as being determined by the structure, organization, and transactional patterns of the family system. This model does not specify the direction of causality, but it allows for the possibility that relationships may be reciprocal and transactional rather than unidirectional (Restifo $\&$ Bogels, 2009). The association between family interactions and adolescent depression appears to be bidirectional. Dysfunctional family environments lead to an increase in depressive symptoms.

The current study aimed to identify the characteristics of family interaction processes in families of adolescents with major depressive disorder (with or without comorbidity) that may differentiate them from families of adolescents with no psychiatric disorders. This study also aimed to collect qualitative observational data to illustrate potential differences between the two groups evaluated.

\section{Method}

\section{Participants}

This is a case-control study conducted at the Universidade Federal de São Paulo (Unifesp) involving 70 participants from 18 families divided into two groups: the first group consists of nine adolescents with major depressive disorder aged between 13-18 and 26 first-degree relatives (case group); the second group consists of nine adolescents with no psychiatric disorders aged between 13-18 and 26 first-degree relatives (the control group). Families in the case group were matched to the control families for adolescent's age, gender, level of education, number and age of siblings, parental marital status, and family economic condition.

All adolescents with major depressive disorder were experiencing the first episode and none were undergoing pharmacological treatment or psychotherapy at the time of psychiatric evaluation.

Throughout 13 consecutive months (from November 2004 to November 2005), only nine adolescents admitted to the Mood Disorders Outpatient Clinic of Unifesp met the criteria in the Diagnostic and Statistical Manual of Mental Disorders (DSM-IV) for major depressive disorder and met the matching requirements for all first-degree relatives. All nine adolescents and their respective first-degree relatives agreed to participate in the present study. The healthy comparison group (adolescents and their relatives) was selected out of 2,194 students aged 13-18 years attending four public high schools located in the university neighborhood. The exclusion criteria for all subjects were the presence of neurological disorders and significant medical diseases detected during the clinical interviews conducted by an experienced child and adolescent psychiatrist.

\section{Instruments}

\section{Family Economic Classification Questionnaire}

The Associação Brasileira de Empresas de Pesquisa (ABEP, Brazilian Association of Research Companies) has developed a family economic classification questionnaire to determine economic classes according to family purchasing power. The instrument is based on several criteria including: the number of home appliances, existence of private 
bathrooms inside or outside the dwelling, and educational level of the head of the household among others. Total scores were used to determine the family economic class: Iow (0-16), middle (17-24), and high (25-34) (ABEP, 2003).

\section{Schedule for Affective Disorders and Schizophrenia for School Age Children-Present and Lifetime}

The Schedule for Affective Disorders and Schizophrenia for School Age Children-Present and Lifetime (K-SADS-PL) is a semi-structured psychiatric interview that ascertains both lifetime and current diagnostic status (Kaufman et al., 1997) based on DSM-IV-TR criteria (American Psychiatric Association, 2000). The Brazilian version of the original English version of the K-SADS-PL (Kaufman et al., 1997) was developed by Brasil and Bordin (2010), and it is a valid instrument to be applied in clinical practice and research involving the mental health of Brazilian children (Brasil \& Bordin, 2010).

\section{Structured Family Interview}

The Structured Family Interview (SFI) comprises six tasks that are assigned to the family as a group (Féres-Carneiro, 1996). Its purpose is to evaluate family structure and functionality. Nine dimensions of family functioning can be evaluated: communication, rules, roles, leadership, conflict, aggressiveness, affect, individuation, and integration . Family interaction processes are identified by the interviewer and by a trained observer who registers the non-verbal signals.

The six tasks that may reveal aspects of family interactions are: Task 1: "Let's imagine that you would have to move out of your house within a month. I would like you to plan your move now, together, describing what it would be like"; Task 2: "When you are doing any activity that seems difficult to complete alone, what do you do?"; Task 3: "Talk about the things you like best about yourself"; Task 4: "Describe a typical holiday celebration in your with any member of your family and someone knocks on the door. When you are about to answer it, the person you were talking to pushes you. What do you do?"; and Task 6: "Each one of you is going to choose one or more members of your family (it can be any person); you have to show the person you chose that you like him/her without saying a word". Task 6 is the only non-verbal task. (FéresCarneiro, 1996).

The Structured Family Interview results were evaluated using a standardized coding system entitled Systemic Family Assessment (SFA). The SFA (Peçanha \& Lacharité, 2007; Peçanha \& PérezRamos, 1999; Peçanha, Pérez-Ramos, \& Lacharité, 2003) is a valid and reliable coding system developed in Brazil, and it has been successfully used in clinical practice and research on family functioning in South and North America with different types of families. The development of the SFA system was based on Carneiro's propositions about family assessment, which have a systemic focus on the family (FéresCarneiro, 1996). The SFA coding system is considered a scientific method that could be applied to the transcultural approach of assessment and intervention (Peçanha, 2008; Peçanha \& Mercier, 2009). Its construct and concurrent validity were determined by Peçanha and Lacharité (2007). This coding system proposes a five-point Likert-type scale to measure the four factors that compose each of the nine family interaction dimensions. The response options are: 1 (very dysfunctional), 2 (dysfunctional), 3 (borderline functionality), 4 (functional), and 5 (very functional). The SFA coding system also determines a score for each dimension, which is the average score across the four factors that compose it. More details on the adaptation, description, and clinical use of the SFA system can be found in Portuguese (Peçanha \& Pérez-Ramos, 1999); French (Peçanha, 2008; Peçanha et al., 2003; Peçanha \& Lacharité, 2007; Peçanha \& Mercier, 2009), and English (Peçanha \& Lacharité, 2007).

\section{Procedures}

The present study was approved by The Research Ethics Committee of Unifesp (Protocol CEP 
1234/04). Written informed consent was obtained from all family members of participant families. Privacy of participants was maintained by using numbers to identify them in the study database.

An experienced child and adolescent psychiatrist and an experienced psychologist applied the Brazilian version of the K-SADS-PL to the cases and controls to make sure that the cases had major depressive disorder (with or without comorbid disorders) and that the controls had no DSM-IV psychiatric disorders. After the diagnosis of major depressive disorder was confirmed, demographics and family functioning data were collected over a one-week period. The case and control families were evaluated following the same procedures.

The family interaction processes were examined in both groups (cases and controls). This real-time interaction was evaluated in one 90-120 minute session with the presence of all family members. An experienced systemic family therapist applied the SFI to each Family. Based on the SFA system, the nine dimensions of family functioning described above were coded. The interview transcripts were independently evaluated by two other systemic family therapists blinded to casecontrol status. The raters scored all interview items using a standardized coding system (overall agreement $=83.5 \%$ ).

Non-parametric statistics was used in the analyses. Descriptive analysis was carried out using the computer program Statistical Package for the Social Sciences (SPSS). An agreement between the two raters of the SFI items was obtained using the intraclass correlation coefficient and the Spearman rank correlation test. Differences in the dimensions of family interaction between the cases and controls were identified by the Wilcoxon test.

\section{Results}

\section{Demographic and clinical characteristics}

Among the cases and controls (aged between 13-18 years), $44.4 \%$ of adolescents in each group were male. There was no significant difference between the two groups in terms of average age (16.8 \pm 1.9 years), school grade (one eighth-grader and eight high school students in the senior year), number of siblings (one adolescent had one, six had two, and two had three siblings), parental marital status (seven couples were married and two were divorced), and family economic condition (all classified as middle category for family economic condition).

Regarding the cases, four adolescents had major depressive disorder only and five had one single comorbid disorder (dysthymia, posttraumatic stress disorder, social phobia, bulimia, and drug abuse, respectively). Two adolescents had their first episode of major depressive disorder between the ages of 13 and 14 years, and seven between the ages of 17 to 18 years. Negative events in this group included: severe family discord (33.3\%), maternal life-threatening illness (11.1\%), death of someone close $(11.1 \%)$, failure to enter college $(11.1 \%)$, and sexual identity problems (11.1\%). Family history of depressive disorder was present in all cases involving the adolescents' parents or grandparents, and/or uncles/aunts.

\section{Family functioning}

Compared to those of the controls, the families of the cases had significantly lower mean scores in all family functioning dimensions evaluated by the SFI, except for the dimensions rules and leadership. Family members showed difficulties communicating with each other, defining their roles, solving conflicts, expressing aggressiveness, demonstrating affection, and maintaining integration and cohesion when acting as a group. Parents had trouble recognizing their children's individuation as someone with separate identity and unique with their own desires, feelings, and thoughts.

The greatest difference between the cases and controls was in the dimension affect ( $p=$ 0.0078) (Figure 1 and Table 1). In families with a depressive adolescent, the family members had difficulties showing affection towards each other. Touching each other was avoided, and when it 


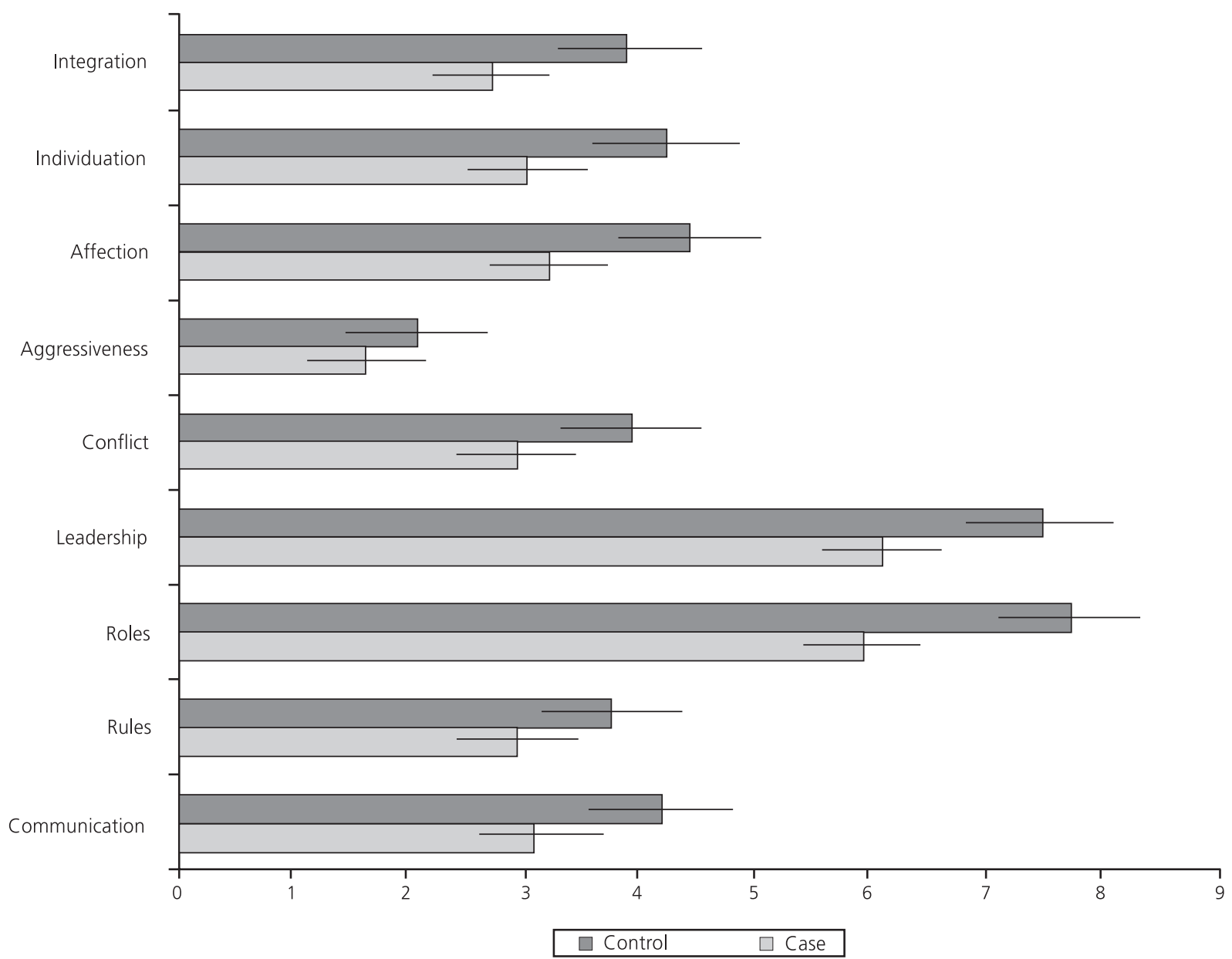

Figure 1. Significant differences between the cases $(N=9)$ and controls $(N=9)$ in the mean scores of seven dimensions of family functioning evaluated by the Structured Family Interview.

happened, individuals passively accepted this demonstration of affection without responding or reacting to it. In addition, parents restrained themselves and tended to wait for their children to take the initiative to show affection.

When considering the six tasks included in the SFI to evaluate family functioning, interesting qualitative data were collected among the families in the two groups, as described below.

Task one (moving) challenged the families in the case group, which was observed by their following frequently asked question: "Do we really have to change?". Most families chose to move to the same neighborhood, and the father leads the move and defines the new place by himself. It was difficult for them to imagine doing something together since discussions were focused on only one member of the family. It was also difficult for the children to express their opinions and to recognize themselves as an active part of the family. This was observed by the following statements: "My parents will decide about the new house, and they won't even notice me". There was divergence of opinion, and it could not be reconciled through negotiation, revealing the presence of potential conflicts. In general, children did not show resistance to change, whereas their parents showed tendency to resist it. In general, it was the mother who made the decisions about what her children would take to their new hypothesized home. The mother's interference in her children's lives, restraining their autonomy and reinforcing immature behavior, was shown through the following question asked by the adolescents: "Should I ask my mother what to take?". 
Table 1

Differences between the cases $(N=9)$ and controls $(N=9)$ in mean scores of nine dimensions of family functioning by the Structured Family Interview

\begin{tabular}{|c|c|c|c|c|c|c|c|c|c|}
\hline \multirow{2}{*}{ Group } & \multirow{2}{*}{$M$} & \multirow{2}{*}{$S D$} & \multirow{2}{*}{ Min } & \multirow{2}{*}{ Max } & \multicolumn{3}{|c|}{ Percentiles } & \multicolumn{2}{|c|}{ Wilcoxon } \\
\hline & & & & & 25 & 50 & 75 & $Z$ & $p$-value \\
\hline \multicolumn{10}{|c|}{ Communication } \\
\hline Cases & 3.10 & 0.85 & 1.63 & 4.19 & 2.41 & 3.31 & 3.81 & - & \multirow{2}{*}{0.0117} \\
\hline Controls & 4.19 & 0.77 & 2.75 & 5.00 & 3.56 & 4.56 & 4.72 & 2.49 & \\
\hline \multicolumn{10}{|l|}{ Rules } \\
\hline Cases & 2.94 & 0.86 & 1.75 & 4.13 & 2.19 & 2.81 & 3.72 & - & \multirow{2}{*}{0.0781} \\
\hline Controls & 3.76 & 0.82 & 2.44 & 4.56 & 3.09 & 4.00 & 4.53 & 1.78 & \\
\hline \multicolumn{10}{|l|}{ Roles } \\
\hline Cases & 5.94 & 2.09 & 3.50 & 8.50 & 3.81 & 6.75 & 7.88 & - & \multirow{2}{*}{0.0469} \\
\hline Controls & 7.74 & 1.27 & 6.00 & 9.13 & 6.50 & 8.25 & 8.94 & 2.03 & \\
\hline \multicolumn{10}{|l|}{ Leadership } \\
\hline Cases & 6.10 & 1.97 & 3.50 & 8.63 & 4.06 & 7.13 & 7.69 & - & \multirow{2}{*}{0.1328} \\
\hline Controls & 7.50 & 1.31 & 5.50 & 9.13 & 6.44 & 7.13 & 8.75 & 1.54 & \\
\hline \multicolumn{10}{|l|}{ Conflict } \\
\hline Cases & 2.94 & 0.95 & 1.50 & 3.88 & 1.91 & 3.25 & 3.78 & - & \multirow{2}{*}{0.0117} \\
\hline Controls & 3.94 & 0.62 & 2.88 & 4.63 & 3.47 & 3.88 & 4.53 & 2.43 & \\
\hline \multicolumn{10}{|c|}{ Aggressiveness } \\
\hline Cases & 1.63 & 0.43 & 0.81 & 2.13 & 1.28 & 1.75 & 1.94 & - & \multirow{2}{*}{0.0195} \\
\hline Controls & 2.07 & 0.37 & 1.31 & 2.44 & 1.84 & 2.19 & 2.38 & 2.32 & \\
\hline \multicolumn{10}{|l|}{ Affection } \\
\hline Cases & 3.22 & 1.05 & 1.56 & 4.56 & 2.06 & 3.75 & 3.91 & - & \multirow{2}{*}{0.0078} \\
\hline Controls & 4.44 & 0.96 & 2.06 & 5.00 & 4.16 & 4.94 & 4.97 & 2.55 & \\
\hline \multicolumn{10}{|l|}{ Individuation } \\
\hline Cases & 3.03 & 1.06 & 1.44 & 4.44 & 1.97 & 3.31 & 3.94 & - & \multirow{2}{*}{0.0108} \\
\hline Controls & 4.24 & 0.87 & 2.06 & 4.88 & 4.13 & 4.44 & 4.81 & 2.55 & \\
\hline \multicolumn{10}{|l|}{ Integration } \\
\hline Cases & 2.72 & 1.16 & 1.25 & 4.31 & 1.63 & 2.88 & 3.81 & - & \multirow{2}{*}{0.0234} \\
\hline Controls & 3.90 & 0.91 & 2.00 & 4.88 & 3.25 & 4.13 & 4.53 & 2.19 & \\
\hline
\end{tabular}

Note: M: Mean; SD: Standard Deviation; Min: Minimum; Max: Maximum; Z: Z-score (Z-scores follow a standard normal distribution with mean = 0 and variance $=1)$.

In the control group, task one was performed in a more democratic way. Parents were in charge of the move, but together with their children they chose the new place. Different points of view could be discussed and conflicts solved in order to reach a consensus, as expressed by one of the parents: "All of us are going to choose our new house together". The opinions expressed by the parents and children showed their intention to be autonomous and independent. One of the mothers said: "We are not going to move close to my husband's family or mine", and one of the adolescents said: "I would rather live in a house, so I could have more privacy and I want a room just for me". If a family member expressed a different opinion by saying for instance "I don't want to move", he or she would not be considered a threat to the family. In addition, all children chose what to take or got just a little help from their mothers.

In task two (asking for help), most families in the case group showed difficulties asking for the help of other family members, which could be observed by one of the parents' responses: "I rarely ask for help. I try to solve it and only ask for help if there is no other way out", and by one of the adolescent's responses: "I don't ask for help and my family doesn't notice when I need help". On the 
other hand, in the control group, most families asked a family member for help. Family collaboration was shown by the following parental statement: "I ask my son for help and he asks for mine too. We can count on each other", and by the following adolescents' statement: "I ask my parents for help".

Regarding task three (things you like best about yourself), children in the case group had difficulties saying what they liked about themselves: "I don't like anything about me" or "Can I say what I don't like (about me)?" Some children were not able to speak by themselves and asked their mother to tell what they liked best about themselves. In the control group, no families showed difficulties related to this task. One of the adolescents said: "I talk a lot, but l'm a good friend and a good daughter".

In task four (holiday), the majority of families in the case group referred to a holiday as a "normal day" and did not mention any activities outside home. One of the parents said: "On a holiday, we do the same things we do every day". None of the parents are used to going out as a couple, and most of them only go out with their children. The following statements highlight the predominance of parenting in the marital role: "We always go out together" and "My wife and I feel weird and empty when we are together without the children". On the other hand, most families in the control group considered holidays different from normal days. These families reported doing extra-familiar activities such as trips and visits to friends or relatives, and when traveling, they usually invite friends to join them. Parents went out alone as a couple or spent time alone, while children usually did their own activities without other family members, with parental consent.

Regarding task five (aggressiveness), in the case group, most husbands and wives would not react if pushed by their partners. Parents would react if pushed by their children, and no children would retort if pushed by their parents. However, most children would react if pushed by siblings. In the control group, reacting to a push would occur more frequently than among the cases, except for husbands who would not react if pushed by their wives in a $100 \%$ of families in the control group.
In task six (affection), a non-verbal task, as mentioned before, family members in the case group hesitated to show affection for family members. All family members avoided taking the initiative to show affection, exhibiting strong tendency to wait for others to start performing the task. It was difficult for them to show affection ("I think she wanted to hug me, but she didn't"), and they were uncertain about whom to choose ("Can I choose all of them?"). Parents preferred their children to be the first to show affection. Families tended to show affection without touching each other. The following display of affections were observed among the mothers: blowing kisses to their daughters and husbands, gesturing as if lulling a baby, drawing a heart in the air and sending it to the whole family, and touching their daughters' hair hands. When families managed to show physical affection by touching, hugging, or kissing each other, individuals passively accepted these displays of affection without reacting to them. In the control group, all families managed to show physical affection by touching, hugging, or kissing, and they responded positively to these demonstrations of affection.

\section{Discussion}

The present study examined the characteristics of family interaction processes in families of adolescents with major depressive disorder comparing them to those of families of adolescents with no psychiatric disorders. During a structured family interview, observational measures provided information about family interaction processes without the intrusion of perceptual biases inherent to self-report measures. It is important to note that observational studies are useful for measuring parent-child interactions since they provide a closer, real time view of how adolescents and parents reciprocally affect each other's feelings, emotions, and behaviors. Observational studies' data can help elucidate what "actually" occurs, and they allow the comparison between parents and youth's perceptions (Restifo \& Bogels, 2009). 
A particular strength of the current investigation is the use of multi-source information (from all members of the family) and a real-time assessment of family interaction processes. This strategy reduces the likelihood that the observed associations are inflated by source variance or are a consequence of biases in family members' perceptions. However, it is important to recognize some limitations of this study, such as the limited sample size and the cross-sectional nature of the study. Despite the reduced sample size and data focused on only one structured interview with each family, it was possible to identify statistically significant differences between the cases and controls in seven dimensions of family functioning (communication, roles, conflict, aggressiveness, affection, individuation and integration) of a total of nine dimensions examined.

Depression is often characterized as a disorder of affection regulation (Gilbert, 2012; Sander \& McCarty, 2005; Sheeber et al., 2001; 2009). In the current study, the greatest difference in family functioning between the cases and controls was in terms of the dimension affect. In the families of cases, difficulties to express affection were observed through the lack of appropriate words, friendly attitudes, and physical contact. Therefore, it can be said that children raised in a family in which there is no demonstration of affection between parents and children and between mother and father, will learn from this behavior and will hide their feelings and emotions. When families allow their children to express their thoughts and feelings, differences between family members are perceived as natural, and negotiations are open in order to solve the differences through agreements (Chiariello \& Orvaschel, 1995).

Expression of affection through physical contact or the sense of touch was the first sense developed, and it is essential for the growth, learning and communication of human beings; it is indispensable for comfort and self-esteem. In terms of family bonds, physical touch appears as the first model of a desired and appreciated relationship. It can be gentle, invigorating, and rewarding because it is able to stimulate feelings of pleasure and well-being. Touching is an act of recognition; it is unpredictable and spontaneous and is given and received in different ways depending on each individual. Holding and cuddling are not only a mother-baby bonding privilege, but also the primary principle of the attachment that Bowlby considered as the source of all psyche (Bowlby, 1984). Skin to skin contact enables mother and baby to look straight into each other's eyes, to smile, and fulfill the desire to communicate. Physical touch helps build self-esteem because the subject feels comforted and recognized by others; and it may be considered as a good way to show affection and respect. Hearing words that express love and affection is not enough, feelings have also to be expressed through physical gestures and actions. Affection is an essential ingredient to develop confidence in the creative capacity of the psyche (Eiguer, 2008).

Family relations have a prospective influence on adolescents' depressive disorders (Kaslow et al., 1994; Restifo \& Bogels, 2009; Sander \& McCarty, 2005; Sheeber et al., 2007). It is essential to consider that the family environment may create stress and be deleterious to the mental health of children and adolescents. Recent findings suggest that the interactions between biological factors and stressful life events may influence the likelihood of experiencing an episode of depressive disorder (McLeod, Weisz, \& Wood, 2007). Therefore, depression in adolescence is likely to be the result of a complex set of interactions between biological vulnerabilities and environmental influences.

A broad array of family factors is associated with youth risk for depression, ranging from parental psychopathology to parental cognitive style to family emotional climate. It is important to collect and consider valuable information about the general atmosphere of the family and to verify how specific family relationships and emotional availability and affection within the family can impact the mental health of children and adolescents (Sander \& McCarty, 2005). A variety of family factors (e.g., parental rearing style, attachment, support, and conflict) may represent environmental adversity that can interact with individual risk factors to produce 
risk mechanisms (Restifo \& Bogels, 2009). For instance, early dysfunction in mother-child relationship may favor the development of certain child behavior patterns to deal with stress that predispose children to depression (Birmaher et al., 1996). However, the mechanisms by which a dysfunctional family interaction may increase child vulnerability to depression have not yet been completely explained.

In the current study, families of depressive adolescents had difficulties not only in demonstrating affection but also in communicating with each other, defining their roles, solving conflicts, expressing aggressiveness, and showing integration and cohesion when acting as a group. Problems in communication are rooted in the complex area of family behavior, and the adults provide the patterns that rule the child's development from childhood to maturity (Chiariello \& Orvaschel, 1995). Depressive parents and parents of depressive children tend to establish a negative, critical, and hostile communication pattern with a deleterious effect on the child's self-esteem and on the way the child learns to communicate with others. Depressive children and children of depressive parents usually establish interplay with parents involving a negative response to their communication style and reinforcing the depressive behavior (Chiariello \& Orvaschel, 1995; Dadds, Sanders, Morrison, \& Rebgetz, 1992). Regarding difficulties in expressing aggressiveness in families of depressive adolescents, a previous study found that parental exposure to their children's depressive behavior reduced their own aggressiveness (Sheeber \& Sorensen, 1998). Parental responses to the adolescent depressive behavior are relatively stable features of family interaction, which are not modifiable by changes in the adolescent depressive condition. Parents do not modify their response to the adolescent depressive behavior, and by doing that, they maintain the interactive pattern and reinforce the adolescent depressive behavior. Therefore, an important point to consider in the family functioning of depressed adolescents is that parents may inadvertently teach their children to behave in a depressive way through a reinforcement process.
In conclusion, families of depressive adolescents have many difficulties in family functioning that may favor the persistence of depressive behavior in adolescents. Thus, a more comprehensive evaluation and treatment of depression in adolescence should not exclude assistance to the entire family. Psychoeducational family interventions improve the adherence to treatment and have been increasingly recommended for the majority of families of depressed adolescents (Compton et al., 2004; Lewinsohn, Rhode, Klein, \& Seeley, 1999). Furthermore, specialized treatment such as family therapy may be recommended especially in highly dysfunctional families (Trowell et al., 2007). It can help better understand the family roles in triggering affective crisis and worsening the clinical presentations of depressive disorders in adolescents. An improvement in family functioning can contribute to minimize the negative influence of family factors on the reoccurrence and severity of depressive episodes in adolescence.

Finally, future research should take into account the fact that a great number of adolescents live in quite diverse home environments (twoparents, single-parents, and step-families). Therefore, the evaluation of how family relations differ across different family structures would be worthwhile. Another aspect to be considered is that few longitudinal studies have been conducted and cross-sectional studies are limited to ascertain the directionality of influence because relationships may be reciprocal and transactional rather than unidirectional. More real-time observational research is required to better understand the mechanisms by which complex interplay between individual factors and family environment may influence youth depression. Observational data of family interaction can provide a relatively independent and possibly less biased index of family relationships. From a developmental perspective, family interaction processes could be responsible for initiating or maintaining factors influencing the onset and course of depression. Studies utilizing direct observation of family functioning may facilitate a better understanding of the patterns that could contribute to depression in adolescents (Chiariello \& Orvaschel, 1995; Messer \& Gross, 1995; Schwartz, Sheeber, Dudgeon, \& Allen, 2012). 


\section{References}

Associação Brasileira de Empresas de Pesquisa. (2003). Critério de classificação econômica Brasil. Recuperado em fevereiro 22, 2011, de http://www.abep.org/ codigosguias/ABEP_CCEB.pdf

American Psychiatric Association. (2000). Diagnostic and statistical manual of mental disorders ( $4^{\text {th }}$ ed., Text rev.). Washington, DC: Author.

Birmaher, B., Bridge, J. A., Williamson, D. E., Brent, D. A., Dahl, R. E., Axelson, D. A., ... Ryan, N. D. (2004). Psychosocial functioning in youths at high risk to develop major depressive disorder. Journal of the American Academy of Child and Adolescent Psychiatry, 43(7), 839-846. http://dx.doi.org/10.1097/01.chi.0000 $128787.88201 .1 \mathrm{~b}$

Birmaher, B., Ryan, N. D., Williamson, D. E., Brent, D. A., Kaufman, J., Dahl, R. E., ... Nelson, B. (1996). Childhood and adolescent depression: A review of the past 10 years. Part I. Journal of the American Academy of Child and Adolescent Psychiatry, 35(11), 1427-1439. http:// dx.doi.org/10.1097/00004583-199611000-00011

Bowlby, J. (1984). Triologia apego e perda (Vol.1-2). São Paulo: Martins Fontes.

Brasil, H. H. A., \& Bordin, I. A. (2010). Convergent validity of K-SADS-PL by comparison with $C B C L$ in a Portuguese speaking outpatient population. $B M C$ Psychiatry, 10, 83. http://dx.doi.org/10.1186/1471-24 4X-10-83

Chiariello, M. A., \& Orvaschel, H. (1995). Patterns of parent-child communication relationship to depression. Clinical Psychology Review, 15(5), 395-407.

Compton, S. N., March, J. M., Brent, D., Albano, A. M., Weersing, V. R., \& Curry, J. (2004). Cognitivebehavioral psychotherapy for anxiety and depressive disorders in children and adolescents: An evidencebased medicine review. Journal of the American Academy of Child and Adolescent Psychiatry, 43(8), 930-959.

Dadds, M. R., Sanders, M. R., Morrison, M., \& Rebgetz, M. (1992). Childhood depression and conduct disorder: II. An analysis of family interactions patterns at home. Journal of Abnormal Psychology, 101(3), 505-513.

Eiguer, A. (2008). Caricias robadas: el cuerpo en la intersubjectividade de los vínculos familiares. Psicoanalisis e Intersubjetividad, 3. Recuperado en marzo 20, 2012, de http://www.psicoanalisiseinter subjetividad.com/website/articulop. asp? id=195\& idioma $=$ \&idd $=3$

Féres-Carneiro, T. F. (1996). Família: diagnóstico e terapia. Rio de Janeiro: Zahar.

Gilbert, E. K. (2012). The neglected role of positive emotion in adolescent psychopathology. Clinical Psychology Review, 32(6), 467-481.
Hughes, E. K., \& Gullone, E. (2008). Internalizing symptoms and disorders in families of adolescents: A review of family systems literature. Clinical Psychology Review, 28(1), 92-117. http://dx.doi.org/10.1016/j.cpr. 2007.04.002

Kaslow, N. J., Deering, C. G., \& Rascusin, G. R. (1994). Depressed children and their families. Clinical Psychology Review, 14(1), 39-59.

Kaufman, J., Birmaher, B., Brent, D., Rao, U., Flynn, C., Moreci, P., ... Ryan, N. (1997). Schedule for affective disorders and schizophrenia for school-age childrenpresent and lifetime version (K-SADS-PL): Initial reliability and validity data. Journal of the American Academy of Child and Adolescent Psychiatry, 36(7), 980-988. http://dx.doi.org/10.1097/00004583199707000-00021

Lewinsohn, P. M., Rhode, P., Klein, D., \& Seeley, J. R. (1999). Natural course of adolescent major depressive disorder; I. Continuity into young adulthood. Journal of the American Academy of Child and Adolescent Psychiatry, 38(1), 56-63.

McLeod, B. D., Weisz, J. R., \& Wood, J. J. (2007). Examining the association between parenting and childhood depression: A meta-analysis. Clinical Psychology Review, 27(8), 986-1003. http://dx.doi.org/ 10.1016/j.cpr.2007.03.001

Messer, S. C., \& Gross, A. M. (1995). Childhood depression and family interaction: A naturalistic observation study. Journal of Clinical Child Psychology, 24(1), 77-88. http://dx. doi.org/10.1207/s1537442 4jсcp2401_10

Peçanha, D. L. (2008). Une pratique systèmique d'intervention familiale. Psychologues et Psychologies, 203, 21-23.

Peçanha, D. L., \& Lacharité, C. (2007). The systemic family assessment system: Its validity with asthmatic children and their families. Psicologia em Estudo, 12(3), 503-512.

Peçanha, D. L., \& Mercier, K. (2009). La pertinence d'une pratique systémique d'intervention familiale au sein de services psychosociaux québécois. Psychologues et Psychologies, 204, 26-27.

Peçanha, D. L., \& Pérez-Ramos, A. M. Q. (1999). Diagnóstico sistêmico da família: novas contribuições. Boletim de Psicologia, 49(110), 17-37.

Peçanha, D. L., Pérez-Ramos, A. M., \& Lacharité, K. (2003). Une méthode systémique d'évaluation du fonctionnement familial: Étude portant sur des familles d'enfants asthmatiques. Revue Québécoise de Psychologie, 24(2), 89-112.

Puissant, S. P., Gauthier, J. M., \& Oirbeek, R. V. (2011). The contribution of social rank and attachment theory to depression in a non clinical sample of adolescents. The Spanish Journal of Psychology, 14(2), 832-842.

Restifo, K., \& Bogels, S. (2009). Family processes in the development of youth depression: Translating the 
evidence to treatment. Clinical Psychology Review, 29(4), 294-316. http://dx.doi.org/10.1016/j.cpr.2009. 02.005

Sander, J. B., \& McCarty, C. A. (2005). Youth depression in the family context: Familial risk factors and models of treatment. Clinical Child and Family Psychology Review, 8(3), 203-219. http://dx.doi.org/10.1007/s10 567-005-6666-3

Schwartz, O. S., Sheeber, L. B., Dudgeon, P., \& Allen, N. B. (2012). Emotion socialization within the family environment and adolescent depression. Clinical Psychology Review, 32(6) 447-453.

Sheeber, L., Hops, H., \& Davis, B. (2001). Family processes in adolescent depression. Clinical Child and Family Psychology Review, 4(1), 19-35. http://dx.doi.org/10. 1023/A:1009524626436

Sheeber, L., \& Sorensen, E. (1998). Family relationships of depressed adolescents: A multimethod assessment. Journal of Clinical Child Psychology, 27(3), 268-277. http://dx.doi.org/10.1207/s15374424jccp2703_4

Sheeber, L. B., Davis, B., Leve, C., Hops, H., \& Tildesley, E. (2007). Adolescents' relationships with their mothers and fathers: Associations with depressive disorder and subdiagnostic symptomatology. Journal of Abnormal Psychology, 116(1), 144-154. http://dx.doi.org/10.10 37/0021-843X.116.1.144

Sheeber, L. B., Allen, N. B., Leve, C., Davis, B., Shortt, J. W., \& Katz, L. F. (2009). Dynamics of affective experience and behavior in depressed adolescents.
Journal Child Psychology and Psychiatry, 50(11), 1419-27. http://dx.doi.org/10.1111/j.1469-7610.2009.02148.x

Slesnick, N., \& Waldron, H. B. (1997). Interpersonal problem-solving interactions of depressed adolescents and their parents. Journal of Family Psychology, 11(2), 234-245.

Stein, D., Williamson, D. E., Birmaher, B., Brent, D. A., Kaufman, J., Dahl, R. E., ... Ryan, N. D. (2000). Parentchild bonding and family functioning in depressed children and children at high risk and low risk for future depression. Journal of the American Academy of Child and Adolescent Psychiatry, 39(11), 1387-1395. http:// dx.doi.org/10.1097/00004583-200011000-00013

Trowell, J., Joffe I., Campbell J., Clemente C., Almqvist F., Soininen M., ... Tsiantis, J. (2007). Childhood depression: A place for psychotherapy. An outcome study comparing individual psychodynamic psychotherapy and family therapy. European Child and Adolescent Psychiatry, 163(3), 157-167.

Weich, S., Patterson, J., Shaw, R., \& Stewart-Brown, S. (2009). Family relationships in childhood and common psychiatric disorders in later life: Systematic review of prospective studies. British Journal of Psychiatry, 194(5), 392-398. http://dx.doi.org/10.1192/bjp.bp.10 7.042515

Received: August 22, 2013

Final version: February 20, 2014

Approved: May 30, 2014 